\title{
The Role of the Motivation in Changes and Performance Assessment of the Managerial Staff in Kosovo Businesses
}

\author{
Hidajet Karaxha \\ Pristina, Republic of Kosovo \\ Halit Karaxha \\ Pristina, Republic of Kosovo \\ Prof. Dr. Berim Ramosaj
}

Faculty of Economy, University of Pristina, Pristina, Republic of Kosovo

Doi: 10.19044/esj.2018.v14n7p224 URL:http://dx.doi.org/10.19044/esj.2018.v14n7p224

\begin{abstract}
Performance evaluation functions as an important tool in adjusting performance potential by removing intermediate barriers and motivating human resources. Each business objectives relate to performance motivation, helping individuals to improve their skills, creating a performance culture, determining which should be promoted, and eliminating employees who have low performance. The paper deals with the moderating role of performance evaluation in motivating managers in Kosovo businesses. This paper consists of the use of a methodology that incorporates a combination of primary and secondary data. The majority of secondary data includes research relevant literature from different libraries, the latest scientific research. Primary data constitute field findings from businesses interviewed in Kosovo. In this study, quantitative approach was used. This approach consists of data collection and analysis in various forms. In order to determine the impact of performance evaluation on motivation of managerial staff, a questionnaire was drafted. This questionnaire was addressed to owners/co-owners, directors, general directors, and all managers in Kosovo's businesses. The last part of this paper is related to discussion of results, conclusions, and recommendations.
\end{abstract}

Keywords: Motivation, role of changes, evaluation of performance, management staff

\section{Introduction}

Business objectives in Kosovo relate to the implementation of motivating practices through bonuses that have a significant impact on increasing the performance of managers by improving their individual skills. 
Huczynski and Buchanan (2007) argued that "Motivation" is "a combination of goals for which man's conduct is driven by processes through which these goals are pursued and achieved, including social factors." Luthans (1992) stated that "Motivation" is a combination of needs, goals, and incentives. Motivation is defined as a process that begins with physiological or psychological deficiencies or needs that activates behavior or a machine that intends a purpose or incentive. Therefore, motivation influences the return of the best performance (Burke \& Litin, 1992, p.523). Decision-making is a process that influences the external and internal motivation of making decisions. Motivation also has an impact on the final wording of the decision. This is also the case such that any decision-making stage may have a direct or indirect impact on motivation and may positively affect the motivational levels of employees, for example through an appropriate motivational program. According to Luecke (2003), communication is an effective tool for motivating employees and increasing their performance. Mullins (1999) opines that the underlying concept of motivation is a driving force that individuals strive for in achieving these goals to meet any need or expectation (Uzonna, 2013, p.201). According to Mc Cornick and Tifflin (2007), motivation may be uncharacteristic and internal. Uncharacteristic motives are those that are external to the job assignment, such as salary, job status, additional benefits, security, promotion, service contract, work environment, and working conditions. On the other hand, internal motivation are those rewards that can be called psychological motives that give the possibility of using someone else's ability, feeling of a challenge and achievement, appreciation, positive recognition, and being treated in a loving way attentive to the workers (Ijah, Muogbo \& Uju, 2013, p.136).

\section{Role of Motivation in Changes}

A key issue in planning for action is on how to motivate employees towards organizational changes. Motivation helps in managing changes in two aspects: creating change readiness and helping to overcome resistance to change (Cummings \& Worley, 2008). Motivational work should be based on knowledge and situations in terms of organization and human resources and the vision of the company. A manager can influence the motivation of his staff from appraisal, reward in various forms, planning their careers and so on (Pohanková, 2010). If employees feel they are not being well compensated, they will not feel good about their work, and managers will have a very good opportunity to motivate employees (Hiam, 2003). Motivation influences to a large extent in managing the change of employees to change aspects in organizations. Motivation usually results in increased employee satisfaction (Luecke \& Beer, 2003). 


\section{Factors that Increase Employee Motivation}

Sara et al. (2004) argued that employees always want to earn a reasonable salary; as a result, money is a significant incentive when it comes to its value and impact. Financial rewards have the capacity to preserve and motivate individuals towards higher performance, especially workers from manufacturing companies, and how an individual can use money to satisfy their needs. Therefore, motivation has a significant impact on the creation, diligence and dedication of employees, being an important factor for employees. Moreover, focusing only on this aspect may worsen the attitude of employees and how they can only pursue financial gains. Fortunately, other non-financial factors have a positive impact on motivation, such as rewards, social recognition, and performance fidelity (Dobre, 2013, p.57). Transactional factors relate to psychological and organizational variables that affect the motivation and performance of employees (Armenakis \& Bedeian, 1999). Schein (1987) further stated that melting is the process of creating motivation and willingness to change. Motivating factors shows that human beings are motivated by the satisfaction and what they stand to benefit for the realization of different needs. Needs depend on many factors and it differs from the person, situation, organization, nature of work, risk, and the level of education of employees, experiences and skills as well as the job position. According to Lin (2007), all employees have their motivational factors to motivate them to perform their job better.

However, motivational factors are categorized in this way and are ranked by the combined average value:

1) Motivational Factor: Work itself and the environment,

2) Motivational Factor: Relations with the supervisor,

3) Motivational Factor: The company itself and issues related to the company,

4) Motivational Factor: Recognition,

5) Motivational Factor: Development and growth,

6) Motivational Factor: Salary and benefits (Hossain \& Hossain, 2012, pp. 23-25).

Consequently, factors which have a significant impact on employee motivation and their productivity include: supervision, working group, work content, salary, and promotion opportunities.

\section{Relationships between Rewards and Employee Performance}

Nowadays, it is very important to reward employees who achieve high levels of performance, because it motivates and controls their work. Indeed, remuneration strategies confirm the level and melting of the non-financial and financial rewards needed to attract, retain, and inspire competent and capable employees capable of making fruitful organizations. Although some of these 
benefits are financial forms, such as salary options and competitive payment, there are many other non-financial benefits that firms can provide their employees with. Therefore, as a manager, it is necessary to know what actually inspires employees, which might not be exactly the same to what stimulates other employees (Gohari, Ahmadloo, Bakhtiari Boroujeni, \& Jafar Hosseinipour, 2013, p.573). Uncertainty of the environment affects the creation of problems in performance appraisal (Eisenhardt, 1985). Rewards practices are essential to reinforcing and stimulating the motivating factor towards achieving organizational performance. Bowen (2000) emphasizes that rewarding is vital to boosting morale and creating goodwill among employees and managers. According to Gibbons (1998), employees need to understand the relationship between business or company objectives, how they contribute, and how they are rewarded to perceive uncertainty and increase the effectiveness of incentive compensation (Zakaria, Noordin, Hussin, \& Sawal, 2011, p.142). Carraher et al. (2006) claims that there should be an effective reward system that holds top performers in organizing rewards associated with their productivity. Gilley et al. (2009) emphasizes that motivating leaders have more opportunities to successfully implement change. In order to maximize the performance of an employee organization, such policies and procedures should be established and should be used to formulate such a reward system based on these policies and procedures that increase employee satisfaction and motivation. Peshkopi (1987) suggested that the salary is directly related to the productivity and reward that depends on the size of an organization. Organizations in today's competitive environment are wanting to determine the reasonable balance and loyalty of employees in the devotion and performance of the organization (Hafiza, Shah, Jamsheed, \& Zaman, 2011, p.328). The Davidson Frame suggests that top executives should provide positive feedback for performance appraisal. Employee wage differentials and low earnings are associated with low morale, lack of engagement, and low productivity. However, this results in a statistically significant relationship between reward, motivation, and satisfaction (Sajuyigbe, Olaoye Bosley, \& Adeyemi, 2013, p. 29). Researches have shown that there is a poor relationship between salary and performance of the organization if there is no system of awards. However, there is a correlated link between promotion and the organization's performance. Strong and very important relationship exists between evaluation and organizational performance. All independent variables mean wages, bonuses, promotion, recognition, and appreciation are positively related to the organization's performance (Yasmeen, Farooq, \& Asghar, 2013, p. 938). The impact of the various categories of rewards programs revealed that the basic salary and benefits of the relationship with the organization's ability helps to promote high levels of employee engagement and motivation compared to incentives, intangible rewards, and leadership quality in the 
engagement. Leadership quality enhances relationships effectively in terms of employee engagement and motivation. As a result, compensation of professionals is very important to attract leaders who have demonstrated their ability to engage employees (Scott \& McMullen, 2010, p.7).

\section{Discussion of research results}

The Role of Employee Motivation by the Company: Motivation prompts employees to improve and work harder to achieve the organization's goals. As a result, it is very important for the efficiency of change. From the survey results, it is seen that $65.2 \%$ of the interviewed businesses have responded to motivating the company to perform the job duties efficiently, $14.8 \%$ of the interviewed businesses feel somewhat motivated to perform the job duties efficiently, $17.5 \%$ of them responded that they felt less motivated by the company, and only $2.5 \%$ responded that they were not at all motivated by the company.

Table I. As a part of the company, do you have adequate motivation from the company to perform your duties efficiently?

\begin{tabular}{|c|c|c|c|c|c|}
\hline \multicolumn{2}{|c|}{} & Frequency & Percentage & $\begin{array}{c}\text { Valuable } \\
\text { percentage }\end{array}$ & $\begin{array}{c}\text { Comitative } \\
\text { Percentage }\end{array}$ \\
\hline \multirow{7}{*}{ Valid } & Many & 260 & 65.2 & 65.2 & 65.2 \\
\cline { 2 - 6 } & $\begin{array}{l}\text { In a } \\
\text { way }\end{array}$ & 59 & 14.8 & 14.8 & 79.9 \\
\cline { 2 - 6 } & Little & 70 & 17.5 & 17.5 & 97.5 \\
\cline { 2 - 6 } & Nothing & 10 & 2.5 & 2.5 & 100.0 \\
\cline { 2 - 6 } & Total & 399 & 100.0 & 100.0 & \\
\hline
\end{tabular}

Source: Author's calculation based on the research results

\section{As a part of the company, do you have adequate motivation from the company to perform your duties efficiently?}

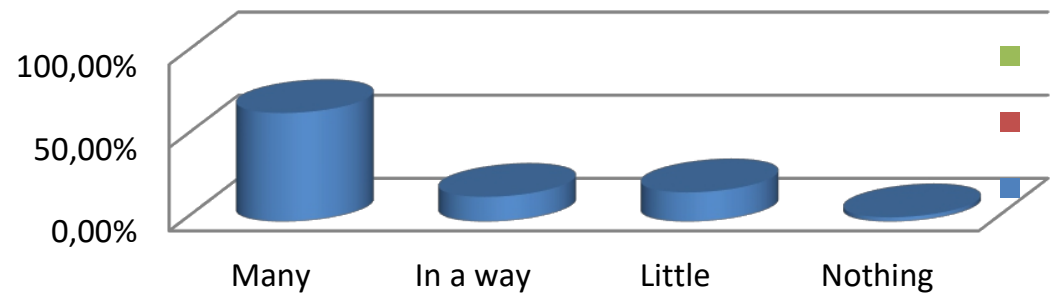

Figure 1. As a part of the company, do you have adequate motivation from the company to perform your duties efficiently?

Furthermore, rewards practices are of great importance in creating goodwill among employees and managers. For you as a part of managerial staff, remuneration practices are essential to reinforcing and stimulating the 
motivating factor towards achieving the performance of the employees in your businesses.

Table II. Essential reward practices to reinforce and stimulate the motivating factor towards achieving the performance of business managers

\begin{tabular}{|c|c|}
\hline $\begin{array}{c}\text { Essential reward practices to reinforce and stimulate the } \\
\text { motivating factor towards achieving the performance of } \\
\text { business managers }\end{array}$ & $\begin{array}{c}\text { Valuable percentage } \\
(\%)\end{array}$ \\
\hline But they are very essential & $74.6 \%$ \\
\hline They are essential & $20.7 \%$ \\
\hline They are somewhat essential & $4.1 \%$ \\
\hline They are not at all essential & $0.6 \%$ \\
\hline Total & $100 \%$ \\
\hline
\end{tabular}

Source: Author's calculation based on the research results

The above table reflects the importance of the remuneration practices related to stimulating motivational factors in increasing the performance of managers in Kosovo businesses. Thus, this results in $74.6 \%$ of respondents who stated that they are very essential, $20.7 \%$ said it was essential, $4.1 \%$ of respondents said they were somewhat substantial, and $0.6 \%$ stated that reward practices are not necessary factors in increasing the performance of managers in their businesses.

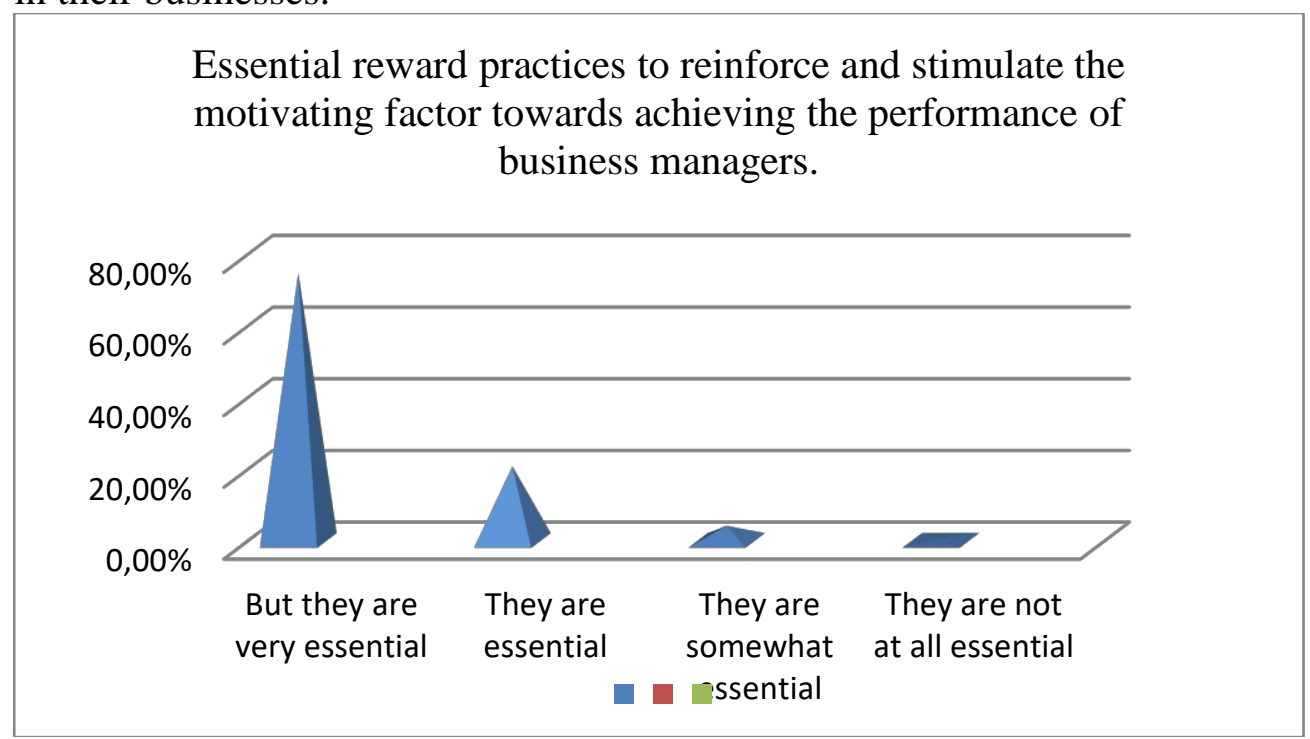

Figure 2. Essential reward practices to reinforce and stimulate the motivating factor towards achieving the performance of business managers

Cross-Tabulated III. Managerial staff performance assessment as a process that ensures employees focus on their work in achieving the organization's mission future 


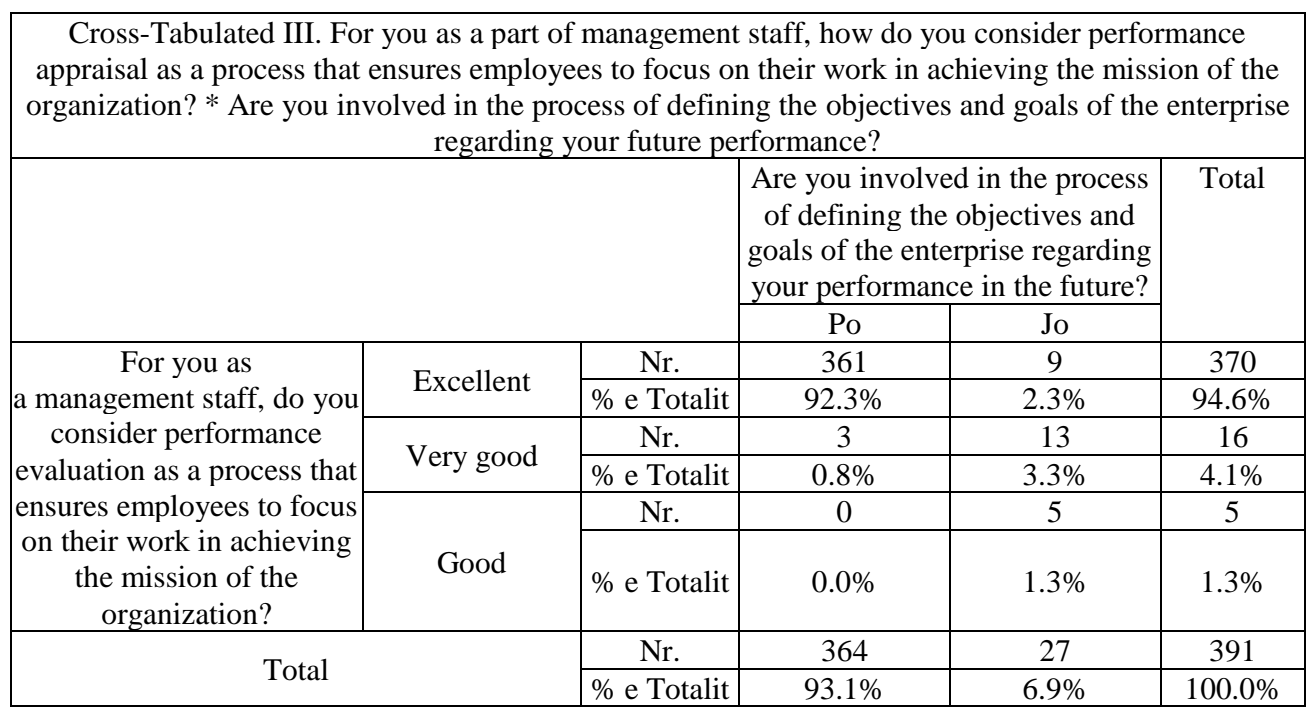

Source: Author's calculation based on the research results

To empirically test the relationship that exists between managerial staff considerations in performance appraisal and managers involvement in the process of identifying business objectives and goals, it is required to evaluate their knowledge in defining their future objectives which will have an impact on increasing the performance of managerial staff. The results obtained from the field were processed and presented in the table above. Starting from the table, it can be seen that $95 \%$ of the staff are involved in the managerial staff assessment process and approximately $92 \%$ of them consider the performance appraisal process in achieving their objectives. Businesses in Kosovo specify the content of duties and responsibilities of their employees in defining the objectives and specific goals that are measurable which each manager must achieve in the following periods. Then the managerial staff meets again in the discussion of the performance of the managers in which the evaluation process is conducted and their performance is discussed in relation to the target objectives or those that have not been realized in order to assist in their realization. Chi-Square Test Results - Reliability between managerial staff consideration in performance evaluation in achieving the mission of the organization and involvement of managers in the process of defining objectives and goals.

\begin{tabular}{|c|c|c|c|}
\hline \multicolumn{5}{|c|}{ 'Chi-Square' Test } \\
\hline & Value & df & Asymp. Sig. (2-sided) \\
\hline Pearson Chi-Square & $216.488^{\text {a }}$ & 2 & .001 \\
\hline Proportion of chance & 96.311 & 2 & .000 \\
\hline Nr. valid case & 391 & & \\
\hline a. 3 Cells (50.0\%) is assumed no. less than 5. The acceptable minimum of no. \\
\hline
\end{tabular}


The Chi-Square test analysis confirms that there is strong evidence of the relationship between managerial staff considerations in performance appraisal and managers involvement in the process of targeting business objectives and goals. However, the value of the Pearson- Chi-square 'is $=.001$ with the degree of freedom' $\mathrm{df}$ ' $=2, \mathrm{p}<0.001$. Since the value of $\mathrm{p}$ is less than 0.05 , this analysis confirms the relationship of significant importance that varies between them.

\section{Conclusion and Recommendations}

Performance assessment, which is a management process to ensure that employees are focusing their work to contribute to the achievement of business objectives, is therefore essential for any business. At the same time, performance appraisal significantly affects employee motivation. Each realistic criterion of performance appraisal has a positive impact on raising employee motivation. Motivation plays an important role in pushing for action, because human being is directed by objectives. Therefore, motivation increases employee results, persistence, productivity, and performance. Also, motivated employees are more inclined to take initiatives than those who have low motivation, suggesting that they will take more responsibility whenever development opportunities are presented to them. These opportunities might include setting clear business objectives to ensure effective and efficient performance over a certain period of time. On the other hand, motivated employees are more engaged and involved in their work than those with low level of motivation.

\section{Recommendations}

Performance evaluation is a measure of how well someone performs relevant job assignments. These measurements are usually made by management staff related to employee selection, motivation, development/response, promotion, training/oversight and staff planning, and performance execution. It is, however, recommended that Kosovo's businesses should be based on effective performance evaluation criteria in the elements related to:

$>\quad$ Motivation of employees, transparency, clear guidance based on objective and informational data in the educational process, trust, and mutual respect;

$>$ Prioritizing the human resources sector as one of the sectors responsible for motivating employees;

$>\quad$ Harmonizing motivational factors with business objectives. 


\section{References:}

1. Armenakis, A.A., Harris, S.G., \& Mossholder, K.W. (1993). 'Creating Readiness for Organizational Change', Human Relations, vol 46, no 6, 681-703.

2. Burd, S., Bazigos, M., Yang Anderson-Rudolph, \& Burke, W. (1996). 'Understanding the management of change, an overvieë of manager's perspectives and assumptions in the 1990s', Journal of Organizational Change, vol 9, no 6, 54-80.

3. Burke, W.W. \& Litwin, G.H. (1992). 'A Casual Model of Organizational Change and Performance' , Journal of Management, vol 18 , no 3, 523-545.

4. Cituar tek Luecke, R. (2003), Managing change and transition, Harvard Business School Press, Boston, MA.

5. Cummings, Th. \& Worley, Ch. (2008). Organization Development \& Change. 9th Edition. South-Western Cengage Learning

6. Dobre, O. (2013). Employee motivation and organizational performance, p.53.

7. Eisenhardt Kathlen, M. (1985). "Control: Organizational and Economic Approaches," Management Science, 31 (February), 134-49.

8. Frame Davidson, J. (2002). The New Project Management. San Francisco: Jossey-Bass

9. Gilley, A., Gilley, J.W., \& McMillan, H.S. (2009). 'Organizational change: motivation, communication, and leadership effectiveness', Performance Improvement Quarterly, 21,4, 75-94.

10. Gohari, P., Ahmadloo, A., Bakhtiari Boroujenwi, M., \& Jafar Hosseinipour, S. (2013). The Relationship between Rewards and Employee Performance, p.546.

11. Hafiza, N., Shah, S., Jamsheed, H., \& Zaman, K. (2011). Relationship Between Rewards and Employee's Motivation in the Non-Profit Organizations of Pakistan, p.328.

12. Hiam, A. (2003). Motivational management: inspiring your people for maximum performance. American Management Association, Amacom

13. Hossain, M. \& Hossain, A. (2012). Factors Affecting Employee's Motivation in the Fast Food Industry: The Case of KFC UK Ltd, p. 2325.

14. Ijah, A., Muogbo, \& Uju, S. (2013). The Influence of Motivation on Employees' Performance: A Study of Some Selected Firms in Anambra State, p.136.

15. Jick, T. (1991). 'Implementing change', class note 9-491-114(Boston: Harvard Business School).

16. Luecke, R., \& Beer, M. (2003). Managing change and transition. Harvard business school press, Boston, massachusetts. 
17. Pohanková, A. (2010). Motivation and decision-making process in managing change within the organization, Human Resources Management \& Ergonomics Volume IV 2, page 1-9.

18. Sajuyigbe, A. S., Olaoye Bosede, O., \& Adeyemi, M.A. (2013). Impact of Reward on Employees Performance in a Selected Manufacturing Companies in Ibadan, Oyo State, Nigeria, p.29.

19. Schein, E.H. (1987). Process Consultation Volume 2: Lessons for Managers and Consultants, Addison-Wesley, Reading, MA. Cituar tek Siegal W., Church A., Javitch M., Waclawski J.

20. Scott, D. \& McMullen, T. (2010), The Impact of Rewards Programs on Employee Engagement, p.7.

21. Uzonna, U. (2013). Impact of motivation on employees "e performance: A case study of CreditWest Bank Cyprus, p.201.

22. Yasmeen, R., Farooq, U., \& Asghar, F. (2013). Impact of Rewards on Organizational Performance: Empirical Evidence from Telecom Sector of Pakistan, p. 938.

23. Zakaria, Z., Noordin, N., Hussin, Z., \& Sawal, M. (2011). The Relationship between Reward Practice and Employees Performance: An Empirical Study, p.142. 